Dept. of Virology,

Animal Health Research Institute, Alexandria Branch

\title{
DETECTION OF ROTA VIRUS IN SOME MOLLUSCS IN ALEXANDRIA GOVERNORATE
}

(With 6 Tables and One Figure)

\section{By}

\section{B.Z. YOUSSEF and Y.S. ABD ELSHAHID*}

*Dept. of Food Hygiene, Animal Health Research Institute, Alexandria Branch (Received at 4/12/2008)

الكشف عن وجود فيروس الروتا في بعض الرخويات فى محافظة الاسكندرية بهجت زكريا بيوسف ، بيوسف ثابث عبا الشهيا

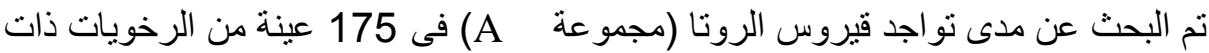

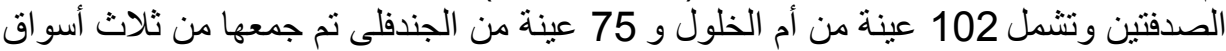

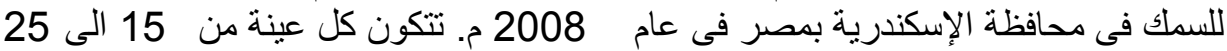

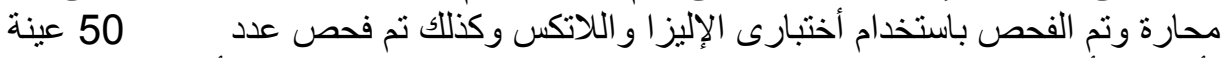

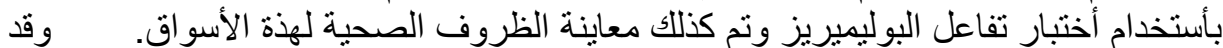

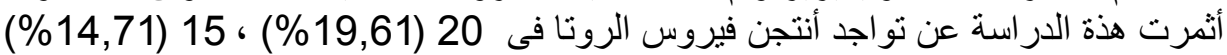

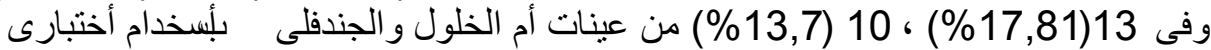
الإليز ا واللاتكس على التو الى وبدون أى إختلافات إحصائية بين الأسواق التئل المختلفة.

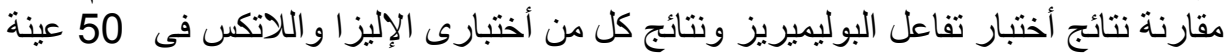

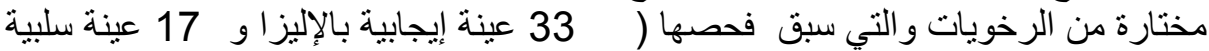

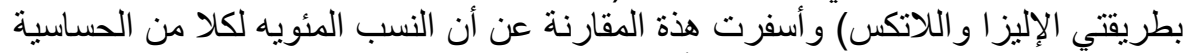

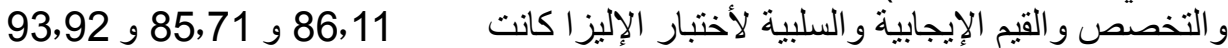

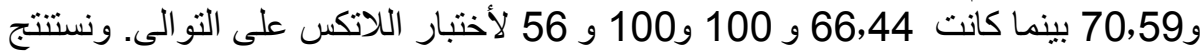

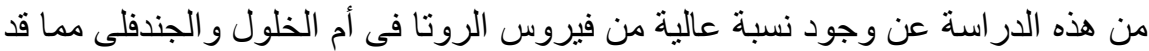

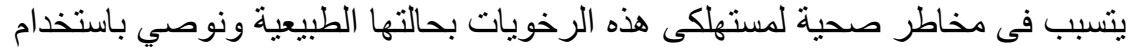

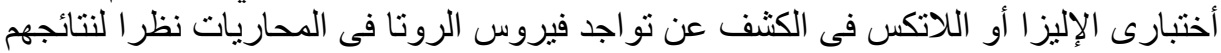

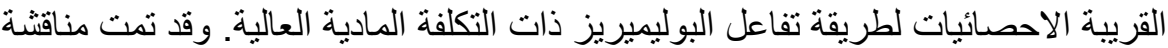

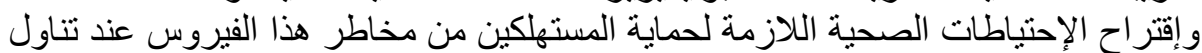

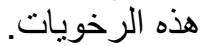

\section{SUMMARY}

Rota viral antigen (Group A) was investigated in 175 molluscan shellfish pools including 102 Om-Elkohloul "Donax tranculus" and 73 Gandofelly "Tapes decussates" from three fish markets along Alexandria 
coast, Egypt, during 2008. Each pool was examined using ELISA and latex agglutination techniques. Fifty selected samples were examined using RT-PCR; also the hygienic conditions of fish markets environment were personally monitored. Rota viral antigen could be detected in 20 $(19.61 \%) \& 15(14.71 \%)$ and in $13(17.81 \%) \& 10(13.7 \%)$ of examined Om-Elkohloul and Gandofelly samples using ELISA \& LA techniques respectively. No significance difference between different fish markets in detecting Rota viral antigen. The comparison between the results of RT-PCR and each of ELISA and Latex techniques for detection of Rota viral antigen was studied in 50 selected molluscs' samples (33 positives by ELISA and 17 negative by both ELISA and LA tests). Accordingly, the sensitivity, specificity, positive and negative predicative values for ELISA test were $86.11 \%, 85.71 \%, 93,94 \%$ and $70.59 \%$, while it was $69.44 \%, 100.0 \%, 100.0 \%$ and $56.0 \%$ for LA test, respectively. In conclusion, this study revealed high detection rate of Rotavirus in molluscan shellfish, which may be one of the most important causative agent of gastroenteritis associated with the consumption of raw molluscs. The good sensitivity, specificity between the results of RTPCR and each of ELISA and LA indicate that the latter two techniques can be used as reliable tools for detection of Rotavirus in shellfish. The corrective actions and hygienic precautions needed to protect consumers against possible hazard of Rotavirus through consumption of these products were discussed and clarified to be employed.

Key words: Virology, Rota virus, molluscs

\section{INTRODUCTION}

Despite major advances and improvements in food and water quality, diagnostic methods, and surveillance systems; food-borne diseases remain a global public health problem (Costantini et al., 2006). Enteric viruses contaminating the environment represent a danger hazard for public health notably that are excreted in stools and can contaminate water and shellfish (Sdiri et al., 2006). The main enteroviruses that cause gastroenteritis are Norovirus, Rotavirus, Sapovirus, Astrovirus, and enteric Adenoviruses (Hansman et al., 2008). Rotavirus is the leading etiologic agent of severe diarrheal disease in infants and young children world wide (Kapikian and Chanock 1990, Patton 1995, Man et al., 2005). Globally, it is the cause of about 600,000 diarrheal deaths every year, in addition to 125 millions cases of Rotavirus diarrhea have been estimated to occur annually in children under the age of 5 years most of 
them in developing countries (Midthun and Kapikian 1996). In developed countries, Rotavirus has been detected in 35 to $52 \%$ of infants and young children hospitalized with acute diarrhea (Konno et al., 1983).

Rotavirus infection is spread primarily by feco-oral route. Although it is a relatively acid labile, it can survive the $\mathrm{pH}$ of a stomach after a meal while it inactivate rapidly at fasting stomach of $\mathrm{pH} 2.0$ (Weiss and Clark, 1985). However at $\mathrm{pH}$ 3.0, inactivation of the Rotavirus is much slower where the infant gastric $\mathrm{pH}$ tends to be approximately 3.2, this probably explain the efficient transmission of Rotavirus in infants (Christensen, 1989). After ingestion the Rotavirus particles are carried to the small intestine where they infect enterocytes leading to change in their structure from columnar to cuboidal. The severity of these changes is correlated with the severity of the resulting illness (Lundgren and Svensson, 2001). The incubation period for Rotavirus disease is approximately 2 days. The disease is characterized by vomiting, watery diarrhea for 3 - 8 days, fever and frequently abdominal pain. Immunity after infection is incomplete, but repeat infections tend to be less severe than the first attack (CDCP, 2007).

Rotavirus is a member of the family Reoviridae (Mathews, 1979), non-enveloped, double stranded RNA, icosahedra structure and $70 \mathrm{~nm}$ in diameter (Desselberger, 1996). There are 7 known subgroups of Rotavirus lettered A through G. Groups A, B and C have been known to infect human and $95 \%$ are caused by group A (Kostouros et al., 2003).

Diseases caused by the consumption of bivalve molluscs shellfish containing pathogenic viruses of human origin is a well known phenomenon, particularly in connection with raw oysters (Lees, 2000). Molluscs are filter feeders that can concentrate more than fourfold in their tissue particles present in the surrounding water, i.e., the filtering of large water volumes, when water is contaminated with human feces, viral pathogens may get trapped in the shellfish (Potasman et al., 2002, Butt et al., 2004). Therefore, the objective of this study is; Detection of Rota viral antigen in Om-Elkhlol and Gandofelly sold in regional fish markets along Alexandria coast, which were destined for human consumption, using ELISA, Latex (LA) and RT-PCR techniques. RTPCR technique is used as gold standard method for confirmation of the results. The corrective actions and hygienic precautions needed to protect consumers against possible hazard of Rotavirus through 
consumption of these molluscs were discussed and clarified to be employed.

\section{MATERIALS and METHODS}

Molluscs sampling: A total of one hundred and seventy five molluscs' pools samples comprising 102 Om-Elkholoul "Donax tranculus" and 73 Gandofelly "Tapes decussates" were collected from three fish markets along Alexandria coast, Egypt, during 2008. Forty two, 22 and 38 of Om Elkhlol and 33, 17 and 23 Gandofelly samples were collected from Shedia, Bakous and Rateb fish markets, respectively. Each pool sample was composed of 15-25 oysters. The samples were kept on ice during shipment and processed immediately after arriving to the laboratory.

Molluscs Processing: The processing was done according to Costantini et al. (2006) as following: shellfish samples were rinsed in water prior to opening. Oysters were shucked with a sterile knife, and the oyster tissues were removed and dissected with sterile scissors and forceps then homogenized with $3.0 \mathrm{ml}$. phosphate buffer saline $(\mathrm{pH} 7.4)$ in sterile homogenizer. The homogenate were then subdivided into aliquots and frozen at $-20^{\circ} \mathrm{C}$. until used.

Virus elution and concentration for ELISA \& LA TESTS: Virus elution and concentration for detection of Rota viral antigen from shellfish was done according to Atmar et al. (1995); the homogenate was transferred to a centrifuge tube and the choloroform-butanol was added to remove tissues.

Virus elution and concentration for RT-PCR technique: The shellfish homogenate was kept frozen in deep freeze at $-20^{\circ} \mathrm{C}$ after addition of RNA late ${ }^{\mathrm{TM}}$ (Ambion cat. no. \# 7620) as a preservative and were subjected to RT-PCR technique for detection of Rotavirus according to Gouvea et al. (1990).

\section{Laboratory Techniques}

1- ELISA technique: RIDASCREEN® Rotavirus (C 0901) ELISA kits, was supplied by R-Biopharm AG, Germany. In this test monoclonal antibodies against a capsid protein of gene 6 (VP6) of the Rotaviruses are applied to the surface of the well in the micro-well plate. One hundred $\mu 1$ of each positive, negative controls and Shellfish extract and were pipetted into each corresponding well. Then $100 \mu 1$ of the enzyme conjugated antibody (Peroxidase conjugated monoclonal antibody prepared in mouse against Rotavirus in stabilized protein solution; contains $0.1 \%$ Kathon) was added and incubated $60 \mathrm{~min}$. at room 
temperature. After washing, $100 \mu \mathrm{l}$ of substrate solution (Urea peroxide/TMB) was added to each well and the plates were incubated at room temperature for $15 \mathrm{~min}$. in the dark. The stopping solution (1N sulphuric acid) was added and the O.D of each well was measured at 450 nm. Cut-Off value was calculated as follow:

Cut-Off value $=$ O.D. of negative control +0.15 .

The sample was considered positive if their O.D. was greater than $10 \%$ above the calculated Cut-Off value, and considered negative if O.D. was more than $10 \%$ below the calculated Cut-Off value. The equivocal values between positive and negative should be repeated.

2- Rapid latex agglutination test (LA): Latex test was carried out according to Haikala et al. (1983) and Hughes et al. (1984) using VIROTECT $^{\circledR}$ ROTA diagnostics Kit (Omega House, United Kingdom). The latex particles are coated with rabbit antibodies prepared against Rotavirus group A. Shellfish extract when added to test latex reagent in the presence of Rotavirus group A antigen agglutinates the latex particles.

3- RT-PCR technique: RT-PCR assay and primers used in this study was done according to Gouvea et al. (1990) using Omni-script Reverse Transcriptase kit (Qiagen).

\section{Primers used}

\begin{tabular}{|c|c|c|c|}
\hline Prime & Sequence (5' - - $^{\prime}$ ) & Position & Strain serotype \\
\hline Beg 9 & GGTTTTAAAAGAGAATGGTTTCTGG & $1-28$ & Wa (1) \\
\hline End 9 & GGTCACATCATACAATTCTAATCTAAG & $1062-1036$ & SA11 (3) \\
\hline
\end{tabular}

RNA Extraction: RNA extraction was done according to Ibrahim et al. (1997) and as follow: One hundred $\mu \mathrm{l}$ of shellfish-RNA late ${ }^{\mathrm{TM}}$ were processed for RNA extraction by Trizol method (Gibco-BRL) which is a monophasic solution of phenol and guandine isothiocynate. The outline method for RNA isolation by Trizol reagent as follow:

Homogenate shellfish -RNA- late ${ }^{\mathrm{TM}}$ in Trizol reagent (50 min. $\rightarrow$ Separate phases (add chloroform-5 min.) $\rightarrow$ Precipitate $R N A \rightarrow$ wash and solubilize.

(The elapsed time less than one hour)

The purified RNA was subjected immediately to reverse transcriptase process.

Reverse transcription: The (ds RNA) of Rotavirus was first denatured by heating the mixture first at $97^{\circ} \mathrm{C}$ for 5 minutes in the thermocycler 
(Beco). Then the tube was transferred quickly to an ice bath to prevent reannealing of the ds RNA, then the reverse transcriptase was added and the tube was transferred back to the thermocycler for incubation at $37^{\circ} \mathrm{C} / 60 \mathrm{~min}$. followed by $94^{\circ} \mathrm{C} / 5 \mathrm{~min}$. The complementary DNA copies (cDNA) from Rotavirus RNA strands were synthesized in $20 \mu \mathrm{l}$ solution (8 $\mu$ l RNase-free water, $2 \mu \mathrm{l}$ of $10 \mathrm{x}$ buffer RT, $2 \mu \mathrm{l}$ of $\mathrm{d}$ NTPs deoxynucleotide triphosphate, $2 \mu \mathrm{l}$ of both primers, $1 \mu \mathrm{l}$ of 4 IU Omnireverse transcriptase enzyme and $5 \mu 1$ of the RNA samples

RT-PCR amplification: The component of the mixture used was; $1 \mu \mathrm{M}$ of each primer, $10 \mu \mathrm{M}$ of each deoxynucleotide triphosphate (d ATP, d GTP, d TTP, d CTP), $10 \mu \mathrm{M}$ tris $\mathrm{Hcl}, 50 \mu \mathrm{M} \mathrm{KCl,} 1.5 \mu \mathrm{M} \mathrm{MgCl} 2,2.5$ units of Tag DNA polymerase (Qiagen), and $10 \mu \mathrm{l}$ of cDNA.

The full length of the gene segment 9 (1,062), encoding the VP7 glycoprotein in human group A Rotavirus, was amplified using primers Beg 9 in the forward direction and primer End 9 in the reverse direction. Amplification was performed in a final volume of $50 \mu 1$ of PCR mixture and the reaction was applied as follow: denaturation at $94^{\circ} \mathrm{C} / 1 \mathrm{~min}$., annealing at $42^{\circ} \mathrm{C} / 2 \mathrm{~min}$. and extension at $72^{\circ} \mathrm{C} / 1 \mathrm{~min}$. (25 cycles), followed by a final extension at $72^{\circ} \mathrm{C}$. Then $10 \mu \mathrm{l}$ of the PCR products were analyzed by electrophoresis on $1.5 \%$ agarose gel containing $0.5 \mathrm{ug} / \mathrm{ml}$ of ethidiun bromide and the DNA was visualized by U.V. light. Positive results showed lane at 1062 base pair as shown in Figure (1).

Personal monitoring of Fish markets: hygienic environment of fish markets, molluscs sellers practices, sewage drainage, Water Cycles (WCs) and seller locations were noticed and evaluated during collection of molluscs samples.

\section{RESULTS}

Tables (1\&2) showed the detection rate of Rota viral antigen in Om-Elkohloul "Donax tranculus" and Gandofelly "Tapes decussates" molluscs at some different fish markets of Alexandria governorate using ELISA and Latex techniques. A total of 20 (19.61\%) and $15(14.71 \%)$ out of 102 examined Om-Elkholoul pools were positive using ELISA and LA tests, respectively. The detection rates in Om-Elkhlol samples were $19.05 \%, 22.73 \%$ and $18.42 \%$ in Shedia, Bakous and Rateb fish markets, respectively, using ELISA technique. Also, a total of 13 $(17.81 \%)$ and $10(13.7 \%)$ out of 73 tested Gandofelly pools were positive using ELISA and LA techniques, respectively with detection 
rates of $15.15 \%, 17.65 \%$ and $21.74 \%$ in Shedia, Bakous and Rateb fish markets, respectively, using ELISA technique.

Tables (3\&4) represent the percent of agreement, sensitivity, specificity, positive and negative predictive values of LA technique, regarding ELISA. There were 95.43, 100, 94.67, 75.76 and 100, respectively, for the detection of Rotavirus in molluscs' pools.

Tables (5\&6) show the comparison between the results of RTPCR and each of ELISA and Latex techniques for detection of Rotavirus in 50 selected molluscs' pools (33 positive by ELISA and 17 pools negative by both ELISA and LA techniques). Out of 36 RT-PCR positive molluscs pools, $31(86.11 \%)$ were positive by ELISA and 2 (14.29\%) out of 14 RT-PCR negatives were positive by ELISA, while 5 pools out of 17 negative by ELISA were positive by RT-PCR. On the other hand, only $25(69.44 \%)$ out of 36 RT-PCR positives were positives by latex test, whereas all negatives RT-PCR were negatives by latex test. Regarding RT-PCR, the sensitivity, specificity, positive and negative predicative values were $86.11 \%, 85.71 \%, 93.94 \%$ and $70.59 \%$ for ELISA test, while it was $69.44 \%, 100.0 \%, 100.0 \%$ and $56.0 \%$ for latex test respectively.

Figure (1): shows Gel electrophoresis for PCR products.

Personal monitoring of different fish markets showed that: poor hygienic environment and very poor condition of WCs without enough water supplies. Unclean and low quality of packaging materials in addition to imperfect cleaning of markets streets and improper periodical removal of waste. Molluscs' sellers had no enough personal hygienic knowledge.

Table 1: Detection rate of Rotavirus in OM-Elkholoul molluscs at different fish markets of Alexandria, Egypt, using ELISA and Latex techniques

\begin{tabular}{|c|c|c|c|c|c|}
\hline \multirow{2}{*}{$\begin{array}{c}\text { Fish } \\
\text { markets }\end{array}$} & \multirow{2}{*}{$\begin{array}{c}\text { No. of } \\
\text { tested } \\
\text { samples }\end{array}$} & $\begin{array}{c}\text { Eo. of +ve } \\
\text { samples }\end{array}$ & percent & $\begin{array}{c}\text { Lo. of +ve } \\
\text { samples }\end{array}$ & percent \\
\cline { 3 - 6 } & 42 & 8 & 19.05 & 7 & 16.67 \\
\hline Shedia* & 22 & 5 & 22.73 & 3 & 13.64 \\
\hline Bakous & 38 & 7 & 18.42 & 5 & 13.16 \\
\hline Rateb & 102 & 20 & 19.61 & 15 & 14.71 \\
\hline Total & & &
\end{tabular}

$\mathrm{X}^{2}=0.17$ (No significance between Shedia and Bakous markets; $\mathrm{P}=0.98$ ). $\mathrm{X}^{2}=0.07$ (No significance between Shedia and Rateb markets; $\mathrm{P}=0.79$ ) 
Table 2: Detection rate of Rotavirus in Gandofelly molluscs at different fish markets of Alexandria, Egypt, using ELISA and Latex techniques.

\begin{tabular}{|c|c|c|c|c|c|}
\hline \multirow[b]{2}{*}{$\begin{array}{l}\text { Fish } \\
\text { markets }\end{array}$} & \multirow{2}{*}{$\begin{array}{c}\text { No. of } \\
\text { tested } \\
\text { samples }\end{array}$} & \multicolumn{2}{|c|}{ ELISA } & \multicolumn{2}{|c|}{ Latex test } \\
\hline & & $\begin{array}{c}\text { No. of +ve } \\
\text { samples }\end{array}$ & percent & $\begin{array}{c}\text { No. of +ve } \\
\text { samples }\end{array}$ & Percent \\
\hline Shedia* & 33 & 5 & 15.15 & 4 & 12.12 \\
\hline Bakous & 17 & 3 & 17.65 & 3 & 17.65 \\
\hline Rateb & 23 & 5 & 21.74 & 3 & 13.04 \\
\hline Total & 73 & 13 & 17.81 & 10 & 13.70 \\
\hline
\end{tabular}

$\mathrm{X}^{2}=0.03$ (No significance between Shedia and Bakous markets; $\mathrm{P}=0.86$ ). $\mathrm{X}^{2}=0.04$ (No significance between Shedia and Rateb markets; $\mathrm{P}=0.83$ )

Table 3: Percentages of agreement between ELISA and Latex techniques for detection of Rotavirus in mollusc's pools in Alexandria, Egypt.

\begin{tabular}{|c|c|c|c|c|}
\hline \multirow{2}{*}{$\begin{array}{c}\text { No. of } \\
\text { tested } \\
\text { samples }\end{array}$} & ELISA & Latex test & \multicolumn{2}{|c|}{ Results of: } \\
\cline { 4 - 5 } & technique & & Agreement & Disagreement \\
\hline 25 & Positive & Positive & 25 & 0 \\
8 & Positive & Negative & 0 & 8 \\
142 & Negative & Negative & 142 & 0 \\
\hline 175 (Total) & \multicolumn{2}{|l}{} & 167 & 8 \\
\hline
\end{tabular}

Percent of agreement $=167 / 175 \times 100=95.43 \%$

Table 4: Percentages of sensitivity and specificity of ELISA in comparison to Latex technique for detection of Rotavirus in mollusc's pools in Alexandria, Egypt.

\begin{tabular}{|c|c|c|c|c|}
\hline \multirow{2}{*}{ Test results } & \multirow{2}{*}{$\begin{array}{c}\text { ELISA } \\
\text { technique }\end{array}$} & \multicolumn{2}{|c|}{ Latex test } & \multirow{2}{*}{ Total } \\
\cline { 3 - 4 } & 33 & Positive & Negative & \\
\hline Positive & $35(\mathrm{~A})$ & $8(\mathrm{~B})$ & 33 \\
\hline Negative & 142 & $0(\mathrm{C})$ & $142(\mathrm{D})$ & 142 \\
\hline Total & 175 & $25(\mathrm{~A}+\mathrm{C})$ & $150(\mathrm{~B}+\mathrm{D})$ & 175 \\
\hline
\end{tabular}

Percent of sensitivity $=A /(A+C) X 100=25 / 25 X 100=100 \%$

Percent of specificity $=\mathrm{D} /(\mathrm{B}+\mathrm{D}) \mathrm{X} 100=142 / 150 \times 100=94.67 \%$

Positive predictive value $=75.76 \%$

Negative predictive value $=100 \%$ 
Table 5: Comparison between the results of RT-PCR, ELISA and Latex techniques for detection of Rotavirus in 50 selected mollusc's pools in Alexandria, Egypt.

\begin{tabular}{|c|c|c|c|c|c|}
\hline \multirow[t]{2}{*}{ Techniques } & \multicolumn{4}{|c|}{ RT-PCR } & \multirow[t]{2}{*}{ Total } \\
\hline & positive & Percent & negative & percent & \\
\hline$\underline{\text { ELISA }}$ & & & & & \\
\hline Positive & 31 & 86.11 & 2 & 14.29 & 33 \\
\hline Negative & 5 & 13.89 & 12 & 85.71 & 17 \\
\hline Total & 36 & 100.0 & 14 & 100.0 & 50 \\
\hline Latex & & & & & \\
\hline Positive & 25 & 69.44 & 0 & 0.00 & 25 \\
\hline Negative & 11 & 30.56 & 14 & 100.0 & 25 \\
\hline Total & 36 & 100.0 & 14 & 100.0 & 50 \\
\hline
\end{tabular}

Table 6: Sensitivity and specificity of ELISA and Latex tests versus RT-PCR

\begin{tabular}{|c|c|c|}
\hline \multirow{2}{*}{ Parameters } & \multicolumn{2}{|c|}{ Percent } \\
\cline { 2 - 3 } & ELISA & Latex test \\
\hline Sensitivity & 86.11 & 69.44 \\
\hline Specificity & 85.71 & 100.0 \\
\hline Positive predictive value & 93.94 & 100.0 \\
\hline Negative predictive value & 70.59 & 56.0 \\
\hline
\end{tabular}

Fig. 1: Gel electrophoresis for PCR products

\begin{tabular}{|l|l|l|l|l|}
\hline 1 & 2 & 3 & 4 & 5 \\
\hline
\end{tabular}

$1062 b p$

- Lane 1: 100 base pair marker.

- Lane 2 and 4: Rota irus positive samples.

- Lane 3 and 5: Rotavirus negative samples. 


\section{DISCUSSION}

Human health problem associated with bivalve shellfish are well documented (Koopmans and Duizer 2004). Viruses are strict intracellular pathogens that can not replicate in food or water. Therefore, food borne viral infectious diseases depends on the initial concentration of virus in the food, host susceptibility, virus stability and the dose required for infection (Costantini et al., 2006). A major public health concern posed by virus contaminated bivalves is that shellfish are often eaten raw or improperly cooked. Heat can render many viruses non infectious, however Rotavirus may be found in cooked shellfish (Abad et al., 1997, Hansman et al., 2008). Rotavirus is non enveloped virus and is generally more environmentally resistant than enveloped virus (Gerba et al., 1996).

Our surveillance showed high percent of detection of Rotavirus in Alexandria molluscan shellfish, Om-Elkohloul "Donax tranculus" and Gandofelly "Tapes decussates", the highest popular sea food molluscs. There was a higher detection rate of Rotavirus antigen in Om-Elkohloul samples $(19.61 \%$ and $14.71 \%)$ than in Gandofelly samples $(17.81 \%$ and $14.70 \%$ ) by ELISA and LA techniques, respectively. There was no significance difference in detection rate between different fish markets. These results were nearly agreed with the results recorded by Le Guyader et al., 1994, Croci et al., 2000, Le Guyader et al., 2000, Macaluso et al., 2004, Gabrieli et al., 2007 with detection rates ranged from 13.89 to $29.9 \%$. Kittigul et al. (2008) recorded low detection rate $(3.33 \%)$ in shellfish samples due to low levels of contamination at collected samples sites. The high detection rate of Rotavirus may be attributed to fecal pollution in sea water along Alexandria coastal area, as reported by many authors (Lackany 1963, El-Sharkaway et al., 1977, Divizia et al., 1997.). The later authors evaluate the quality of the seawater samples taken at different points on the coast of Alexandria, Egypt. Samples were collected in 6 different points from which three samples were positive for the presence of enteric viruses. In another study in India, the authors studied the prevalence of human enteric viruses in bivalve molluscan shellfish and shrimp to assess the extent of fecal pollution of coastal environment (Umesha et al., 2008). High detection rate reaching 44\% was detected by Show (1999) and Hansman et al. (2008) due to contamination of water by sewage

The higher detection rate of Rotavirus by ELISA $(19.61 \%$ \& $17.81 \%)$ than Latex test $(14.71 \% \& 13.7 \%)$ in Om-Elkohloul and Gandofelly samples, respectively may be attributed to the following: the 
viral titer could be lower than technique sensitivity, so ELISA requires $10^{5}-10^{6}$ viral particles/gram that may not enough for LA test and the shellfish extract may contain non specific inhibitors resulting in weak agglutination reaction, not detected by ELISA (Arguelles et al., 2000).

In the present study, the percent of agreement, sensitivity, specificity, positive and negative predictive values of LA test when compared to ELISA were 95.43\%, 100.0\%, 94.67\%, $75.76 \%$ and $100.0 \%$ respectively. LA test was of low complexity, easy to interpret and provided a rapid diagnosis in a short time. It showed a reasonable amount of sensitivity and a high degree of specificity, proving to be a suitable test for diagnosis of Rotavirus in the examined samples. Nearly similar results were reported by many other workers (Ibrahim et al., 1990, Raboni et al., 2002, Altindis et al., 2004).

RT-PCR results, inspite of its cost, showed a highly sensitive and specific method for detection of Rotavirus, which provides a rapid and efficient means of obtaining large quantities of cDNA. It is important to note that empty particles of Rotavirus can also be detected by VP6-ELISA, thereby enhancing the sensitivity of the assay by detecting virus fragments inaccessible by RT-PCR (Adler et al., 2005). That may explain our findings as $2(14.29 \%)$ of negative by RT-PCR were positive by ELISA. These proteins (VP6) are more stable compared to RNA and therefore allow for detection of Rotavirus in samples where the RNA is lost due to harsh conditions.

The observed poor hygienic environment of fish markets and unhygienic molluscs' handlers practices (Personal monitoring); may add an access load of the Rotavirus contaminations to Om-Elkholoul and Gandofelly molluscs.

In conclusion, this study showed a high detection rate of Rotavirus in shellfish that may increase the incidence of diarrheal gastroenteritis due to consumption of Om-Elkholoul and Gandofelly molluscs. There was a good sensitivity and specificity between the results of RT-PCR and each of ELISA and LA techniques, therefore; it could be recommended the following:

- The use of either ELISA or LA technique as reliable tool for detection of Rotavirus in shellfish.

- The applying of corrective actions and hygienic precautions to avoid Rotavirus infection and ensure safety and fitness of these molluscs to consumers that clarified to be employed as following:

1- Prevention of sewage drain into sea water, even treated, to prohibit the main source of Rotavirus contamination. The stability of Rotavirus 
in environmental waters, and their resistance to physical, chemical treatment processes in sewage treatment plants may facilitate their transmission (Carol Shieh et al., 2000).

2- Application of obligatory hygienic training programs, personal hygiene and good hygienic practices, for fishermen and molluscs sellers. 3- Periodical hygienic inspection of fish markets to ensure perfect cleaning and removal of waste, continual upgrading of hygienic certificates for sellers and renewal of all WCs with enough water supplies.

4- Awareness for customers to avoid eating raw Om-Elkholoul or Gandofelly and should apply hygienic practices in handling and efficient cooking of these molluscs to ensure getting red off possible risk of Rotavirus and other enteric viruses.

\section{AKNOWEDGMENT}

We wish to thank Prof Dr Gerges N. Ass Prof., Dept Cell Biology, Medical College of Wisconsin for supplying us the requested Kits of this study, and Prof. Dr. Hadia A Donia, Prof. of Virology in Virology department and head of PCR unit at High Institute of Public Health, Alexandria University for her scientific help.

\section{REFERENCES}

Abad, F.X.; Pinto, R.M.; Gajardo, R. and Bosch, A. (1997): Viruses in mussels: public health implications and depuration. J. Food Prot; 60:677-681

Aldler, A.; Schulz, S.; Fischer, R. and Nimeyer, C.M. (2005): Detection of rotavirus from stool samples using a standardized immunoPCR method with end point and real time detection. Biochem Biophys Res. Commun; 333 (4): 1289-94.

Altindis, M.; Yavru, S.; Simsek, A.; Ozkul, A.; Ceri, A. and Koc, H. (2004): Rotavirus infection in children with acute diarrhea as detected by Latex Agglutination, ELISA and Polyacrylamide Gel Electrophoresis. Indian Pediatr; 41: 590-9

Arguelles, M.H.; Villegas, G.A.; Castello, A.; Abrami, A.; Ghelli, G. and Semorile, L. (2000): VP6 and VP4 genotyping of human group A rotavirus in Buenos Aires, Argentina. J. Clin. Microbiol; 38 (1): $252-9$

Atmar, R.L.; Neill, F.H.; Romalde, J.L.; Le Guyader, F.; Woodley, C.M.; Metcalf, T.G. and Estes, M.K. (1995): Detection of Norwalk virus and hepatitis A virus in shellfish tissues with the PCR. Appl. Environ. Microbiol; 61: 3014-3018 
Butt, A.A.; Aldridge, K.E. and Sanders, C.V. (2004): Infections related to the ingestion of seafood. I. Viral and bacterial infections. Lancet Infect. Dis. 4:201-212

Carol Shieh, Y.S.; Monroe, S.S.; Fankhauser, R.L.; Langlois, G.W.; Burkhardt, W. and Baric, R.S. (2000): Detection of Norwalklike virus in shellfish implicated in illness. J. Infect Dis; 181: 360-366

CDCP (Centers for Disease Control and Prevention) (2007): About Rotavirus. Public Inquiries: National Center for Immunization and Respiratory Diseases1-800-CDC-INFO (232-4636).

Christensen, M. (1989): Human viral gastroenteritis. Clin. Microbiol Rev.; 2 (1): 51-89

Costantini, V.; Fabienne, L., Lynn, J., Le Guyader, F.S. and Saif, L.J. (2006): Human and Animal Enteric Caliciviruses in Oysters from Different Coastal Regions of the United States. Appl. Environ. Microbiol; 72 (3): 1800-9

Croci, L.; De Medici, D.; Scalfaro, C.; Fiore, A.; Divizia, M.; Donia, D.; Cosentino, A.M.; Moretti, P. and Costantini, G. (2000): Determination of enteroviruses, hepatitis A virus, Bacteriophages and Escherichia coli in Adriatic Sea mussels J. Appl. Microbiol; 88(2): 293-8

Desselberger, U. (1996): Genome rearrangements of rotavirus. Arch. Virol. Suppl; 12: 37-51

Divizia, M.; Ruscio, V.; Donia, D.; el Ghazzawi, E.; Elcherbini, E.; Gabrieli, R.; Gamil, F.; Kader, O.; Zaki, A.; Renganathan, E. and Panà, A. (1997): Microbiological quality of coastal sea water of Alexandria, Egypt. Ann. Ig; 9 (4): 289-94

El-Sharkaway, F.M.; El-Molla, A.H.; Sharaf, E.D.S.; Rakha, A.E.S.; Galal, S.S.; Hassan, M.N.R. and Ali, M.E. (1977): The final report on the study of contamination of Alexandria coastal waters as a result of sewage disposal in the sea. High Institute of Public Health, Alexandria University.

Gabrieli, R.; Macaluso, A.; Lanni, L.; Saccares, S., Di Giamberardino, F.; Cencioni, B.; Petrinca, A.R. and Divizia, M. (2007): Enteric viruses in molluscan shellfish New Microbiol; 30 (4): 471-5.

Gerba, C.P.; Rose, J.B.; Haas, C.N. and Crabtree, K.D. (1996): Waterborne rotavirus: a risk assessment. Water Res. 30: 29-30.

Gouvea, V.; Glass, R.I.; Woods, P.A.; Taniguchi, K.; Clark, H.F. and Forrester, B. (1990): Polymerase Chain Reaction amplification 
and typing of rotavirus nucleic acid from stool specimens. J. Clin. Microbiol; 28: 276-82.

Haikala, R.H.; kokkonen, J.O.; Leinonen, M.L.; Nurmi, T.; Mantyjarvi, R. and Sakkinen, H.K. (1983): Rapid detection of rotavirus in stool by latex agglutination: comparison with radioimmunoassay and electron microscopy and clinical evaluation of the test. J. Med. Virol; 11: 91-7.

Hansman, G.S.; Oka, T.; Tian, C.L.I.; Nishio, O.; Noda, M. and Takeda, N. (2008): Detection of Human Enteric Viruses in Japanese Clams. J. Food Prot.; 71 (8): 1689-1695.

Hughes, J.H.; Tuomari, A.V.; Mann, D.R. and Hamparian, V.V. (1984): Latex immunoassay for rapid detection of rotavirus. J. Clin. Microbiol.; 20: 441-7.

Ibrahim, A.A.; Turell, M.J.; Knauert, F.K. and Lofts, R.S. (1997): Detection of Rift Valley Fever virus in mosquito by RT-PCR. Mol. Cell. Probes; 11(1): 49-58.

Ibrahim, O.S.; Sunderland, D. and Hart, C.A. (1990): Comparison of four methods for detection of rotavirus in feces. Trop Doct; 20: 30-32.

Kapikian, A.Z. and Chanock, R.M. (1990): Rotavirus. Virology 2nd ed; New York: Raven Press; p. 1353-404.

Kittigul, L.; Pombubpa, K.; Rattanatham, T.; Diraphat, P.; Utrarachkij, F.; Pungchitton, S. and Ushijima, H. (2008): Development of a method for concentrating and detecting Rotavirus in oysters. Int. J. Food Microbiol.; 122 (1-2): 204-10.

Konno, T.; Suzuki, H.; Katsushima, N.; Imai, A.; Tazawa, F. and Kutsuzawa, T. (1983): Influence of temperature and relative humidity on human Rotavirus infection in Japan. J. Infect. Dis.; 147: $125-8$.

Koopmans, M. and Duizer, F. (2004): Food borne viruses: an emerging problem. Int. J. Food Microbiol; 90: 23-41.

Kostouros, E.; Siu, K.; Ford Jones, E.L.; Petric, M. and Tellier, R. (2003): Characterization of Rotavirus strain from children in Toronto, Canada. J. Clin. Virol; 53 (4): 410-49

Lackany, A. (1963): Further study on pollution of the coastal waters of Alexandria. Alex. Med. J.; 9: 407-415.

Lees, D. (2000): Viruses and bivalve shellfish. Int. J. Food Microbiol; 59: 81-116.

Le Guyader, F.; Haugarreau, L.; Miossec, L.; Dubois, E. and Pommepuy, M. (2000): Three-years study to assess human 
enteric viruses in shellfish. Appl. Environ. Microbiol; 66 (8): 3241-8.

Le Guyader, F.; Dubois, E.; Menard, D. and Pommepuy, M. (1994):

Detection of hepatitis A virus, rotavirus, and enteroviruses in naturally contaminated shellfish and sediment by reverse transcription-semi nested PCR. Appl. Environ. Microbiol; 60 (10): 3665-71.

Lundgren, O. and Svensson, L. (2001): Pathogenesis of Rotavirus diarrhea. Microbes Infect; 3 (13): 1145-56.

Macaluso, A.; Gabrieli, R.; Lanni, L.; Saccares, S.; Panà, A. and Divizia, M. (2004): Enteric viruses and bacteriological parameters in molluscs. Ann Ig.; 16 (1-2): 237-45.

Man, N.V.; Luan, L.T.; Trach, D.D.; Thanh, N.T.; Tu, P.V. and Long, N.T. (2005): Epidemiological profile and burden of Rotavirus diarrhea in Vietnam: 5 years of sentinel hospital surveillance, 1998-2003. J. Infect. Dis.; 192 (1): 127-32.

Mathews, R.E. (1979): The classification and nomenclature of viruses. Intervirology; 11:133-5.

Midthun, K. and Kapikian, A.Z. (1996): Rotavirus vaccines: an overview. Clin. Microbiol Rev.; 9 (3): 423-34.

Patton, J.T. (1995): Structure and function of the rotavirus RNA-binding proteins. J. Gen. Virol.; 76: 2633-44.

Potasman, L.; Paz, A. and Odeh, M. (2002): Infectious outbreaks associated with bivalve shellfish consumption: a worldwide perspective. Clin. Infect Dis.; 35: 921-928.

Raboni, S.M.; Nogueira, M.B.; Hakim, V.M.; Torrecilha, V.T.; Lerner H. and Tsuchiya, L.R. (2002): Comparison of Latex agglutination with Enzyme Immunoassay for detection of Rotavirus in fecal specimens. Am. J. Clin. Pathol; 117: 392-4.

Sdiri, K.; Khelifi, H.; Belghith, K. and Aouni, M. (2006): Comparison of cell culture and RT-PCR for the detection of enteroviruses in sewage and shellfish. Pathol. Biol. (Paris); 54 (5): 280-4.

Shaw, R. (1999): Viral infections of the gastrointestinal tract. Viral Infect Gastrointestinal; 15 (1): 53-59.

Umesha, K.R.; Bhavani, N.C.; Venugopal, M.N.; Karunasagar, I.; Krohne, G. and Karunasagar, I. (2008): Prevalence of human pathogenic enteric viruses in bivalve molluscan shellfish and cultured shrimp in south west coast of India. Int $\mathbf{J}$ Food Microbiol; 122 (3): 279-86. 
Weiss, C. and Clark, H.F. (1985): Rapid inactivation of Rotaviruses by exposure to acid buffer or acidic gastric juice, J. Gen. Virol; 66: $2725-30$ 